\title{
TRPV1 channel inhibition contributes to the antinociceptive effects of Croton macrostachyus extract in mice
}

Télesphore Benoît Nguelefack ${ }^{1,2^{*}}$, Rafael Cypriano Dutra ${ }^{2,3}$, Ana Flavia Paszcuk ${ }^{2}$, Edinéia Lemos de Andrade ${ }^{2}$ and João Batista Calixto ${ }^{2,4}$

\begin{abstract}
Background: Previous study showed that extracts from Croton macrostachyus (Euphorbiaceae) exhibit analgesic effects in acute pain models. The present study evaluates the antinociceptive properties of the methanol/methylene chloride extract (MECM) of the stem bark of this plant using mice models of persistent inflammatory and neuropathic pain, and assesses its mechanism of action.

Methods: MECM was tested on Complete Freund adjuvant (CFA)-induced persistent thermal and mechanical pain, neuropathic pain induced by partial sciatic nerve ligation (PSNL), prostaglandin $E_{2}\left(P_{G} E_{2}\right.$ )-induced acute mechanical hyperalgesia, as well as on nociception induced by capsaicin in mice. Mechanical hyperalgesia was assessed using von Frey hair in awake mice. The mechanism of action of MECM was evaluated by using glibenclamide on $\mathrm{PGE}_{2}$-induced hyperalgesia or rimonabant on capsaicin-induced pain.

Results: MECM administered orally at the doses of 250 and $500 \mathrm{mg} / \mathrm{kg}$, induced long lasting and significant antihyperalgesic effects on CFA-inflammatory and PSNL-induced neuropathic pain. MECM significantly reduced the mechanical hyperalgesia induced by $\mathrm{PGE}_{2}$ either when administered preventively or therapeutically. MECM also significantly and time dependently inhibited the capsaicin-induced nociception. These effects were not affected by glibenclamide or by rimonabant.

Conclusions: The present results demonstrate that the oral administration of MECM to mice resulted in long lasting antihyperalgesic activity in inflammatory and neuropathic pain as well as in acute and persistent pain. The mechanism underlying the long lasting MECM antihyperalgesic effect is currently unknown, but might be mediated, at least partially, through the modulation of TRPV1 receptors.
\end{abstract}

Keywords: Croton macrostachyus, Neuropathic pain, Inflammatory pain, Antinociceptive, TRPV1

\section{Background}

Pain is a subjective and unpleasant experience willing to protect the organism against harmful stimuli. The unpleasant sensation in acute pain and the useless longterm emotional experience of suffering in chronic pain have turn pain to become an entire disease that needs

\footnotetext{
* Correspondence: nguelefack@yahoo.fr

'Laboratory of Animal Physiology and Phytopharmacology, Department of Animal Biology, Faculty of Sciences, University of Dschang, P.O. Box 67, Dschang, Cameroon

2Department of Pharmacology, Centre of Biological Sciences, Universidade Federal de Santa Catarina UFSC, Campus Universitario, Rua Ferreira Lima 82, Trindade, 88049-900 Florianopolis, SC, Brazil

Full list of author information is available at the end of the article
}

to be alleviated as early as possible. In addition, unremitting pain is frequently associated with anxiety, depression, loss of independence, and interference with work and relationships. The anxiety and the emotion resulting from pain, reciprocally strengthen the pain and thereby, maintain a vicious circle that worse the patient condition. Furthermore, chronic neuropathic pain can acquire with time an important inflammatory component $[1,2]$ which is thought to account for neuronal plasticity associated to pain. Indeed, it has been shown that in both neuropathic and inflammatory pain conditions various neuronal cells proteins are up regulated, including TRPV1 receptors [3]. Apart from TRPV1 antagonists, the activity

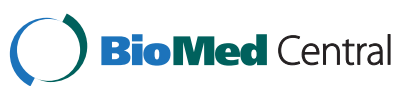

(c) 2015 Nguelefack et al. Open Access This article is distributed under the terms of the Creative Commons Attribution 4.0 International License (http://creativecommons.org/licenses/by/4.0/), which permits unrestricted use, distribution, and reproduction in any medium, provided you give appropriate credit to the original author(s) and the source, provide a link to the Creative Commons license, and indicate if changes were made. The Creative Commons Public Domain Dedication waiver (http://creativecommons.org/publicdomain/zero/1.0/) applies to the data made available in this article, unless otherwise stated. 
of TRPV1 channels can be modulated by cannabinoid receptors which are collocated in the same nerve endings or by ATP sensitive potassium channels. These cell structures are potential targets for pain management.

For many years, research has been focused on seeking medicine that can conveniently address chronic pain. But, still more than 40 to $50 \%$ of patients in routine practice settings fail to achieve adequate relief especially those suffering from neuropathic pain [4]. Thus, pain, especially chronic pain, resulting from inflamed tissues or directly from nerve injury are now considered to be a public health problem of major proportions. Hence, there is a great need for the development of new, safe and better analgesic drugs for the alleviation and control of acute and chronic, inflammatory and neuropathic pain. Medicinal plants are considered as an important source of active molecules of pharmacological interest, given their efficiency proved against many diseases and the fact that more than $50 \%$ of the actual manufactured drugs are from plant or derivatives of plant compounds $[5,6]$.

Croton macrostachyus (Hochst) pipe cleaner ex and Galinier, is a plant used in African folk medicine to treat different ailments, including pain and inflammation [7, 8]. Indeed, previous studies have shown that aqueous and organic extracts from the stem bark of $C$. macrostachyus given orally, possess antinociceptive and anti-inflammatory activities in distinct acute animal models [9]. The present study aimed at providing additional insight about the antinociceptive effects of the methanol/methylene chloride extract of the stem bark of C. macrostachyus in different models of chronic inflammatory and neuropathic pain and to evaluate its preliminary mechanisms of action.

\section{Methods}

\section{Plant collection and extraction}

Plant material was harvested in Bagangté (West, Cameroon) and identified at the Cameroon National Herbarium in comparison to the existing Voucher specimen (5696/SRF/CAM). The stem bark was sun dried and pulverized. Six kilograms of C. macrostachyus powder were macerated in $10 \mathrm{~L}$ of a mixture of methanol/methylene chloride $\left(\mathrm{CH}_{3} \mathrm{OH} / \mathrm{CH}_{2} \mathrm{Cl}_{2}, 1: 1 \mathrm{v} / \mathrm{v}\right)$ for 2 days at room temperature, filtered and concentrated at 45 and $65{ }^{\circ} \mathrm{C}$ successively, using a rotary evaporator. This process yielded $160 \mathrm{~g}$ of $\mathrm{CH}_{3} \mathrm{OH} / \mathrm{CH}_{2} \mathrm{Cl}_{2}$ extract, which correspond to $2.67 \%$ yield. This extract has been shown to possess alkaloids, phenols, terpernoids and flavonoids [9], including lupeol, betulin floridolide A, hardwickic acid and 12-oxo-hardwickic acid [10].

\section{Animals}

Swiss mice (25-35 g) of both sexes, aged 6 to 8 weeks were used in the present study. Animals were obtained from the central animal house of the Department of
Pharmacology from Federal University of Santa Catarina, Brazil. They were acclimatized for at least 1 week in the laboratory at a controlled temperature $\left(22 \pm 1{ }^{\circ} \mathrm{C}\right)$, humidity (50-80 \%), under a 12-h light/dark cycle with free access to standard commercialized rodent diet and filtrated water. The number of mice used was the minimum possible to determine consistent effects of the drug treatments (See figures). All protocols were submitted and approved by the Ethical Committee for use of Animals of the Federal University of Santa Catarina (protocol no. PP00496) and conformed to the guidelines for the study of pain in awake animals established by the International Association for the Study of Pain.

\section{Experimentation}

\section{Mechanical hyperalgesia behaviour assessment}

Mice were acclimatized for at least 1 hour in individual transparent cages $(9 \times 7 \times 11 \mathrm{~cm})$ placed on an elevated wire mesh platforms. They were evaluated for paw withdrawal using $0.4 \mathrm{~g}$ von Frey hair (VFH, Stoelting, Chicago, IL, USA). Each animal was essayed 10 times and the result was expressed as percentage of response (paw withdrawal) to the number of stimulations, as previously published [11].

\section{Complete Freund Adjuvant (CFA) - induced mechanical hyperalgesia}

Before any treatment, the baseline percentage withdrawal was measured. Then, animals were treated orally with vehicle $(10 \mathrm{ml} / \mathrm{kg})$, MECM (250 or $500 \mathrm{mg} / \mathrm{kg}$ ) or gabapentin (used as positive control drug, $70 \mathrm{mg} / \mathrm{kg}$ ). One hour after treatment, they were slightly restrained and received an intraplantar injection of $20 \mu \mathrm{l}$ of CFA $(100 \%)$ and returned in wire mesh plate form. The frequency of response to von Frey hair was then evaluated at 1, 2, 4, 6, 8 and $24 \mathrm{~h}$ time points after CFA injection. After the $24 \mathrm{~h}$ hyperalgesia evaluation, animals received another dose of treatment and were further kept untreated while evaluating pain behavior until the response frequency was equal to that of control group receiving vehicle [11]. Then they received once daily treatment and were evaluated for pain sensation $24 \mathrm{~h}$ after each administration until 14 days post CFA. The aim of this protocol was to verify if repeated treatment could result in a long lasting analgesic effect.

Neuropathic pain induced by sciatic nerve partial ligation To evaluate neuropathic pain-like behavior, the procedure was similar to that described previously [12]. Mice were anaesthetized by intraperitoneal injection of chloral hydrate $7 \%(0.8 \mathrm{ml} / \mathrm{kg})$, after the measurement of the basal response to mechanical stimulation with von Frey hair $0.4 \mathrm{~g}$. The right common sciatic nerve was exposed at the level of the mid-thigh, proximal to the nerve trifurcation. 
The exposed nerve was partially ( $1 / 3$ to $1 / 2)$ ligatured using 8.0 suture needles. Care was taken to preserve epineural circulation. The tight was slowly stretched until the ispilateral hind foot elicited a brief twitch. Then the incision was sutured and treated with iodine. Five days after the surgical intervention, a second mechanical basal pain behavior was assayed to assure the effectiveness of pain installation. Then, animals were treated orally either with vehicle, MECM (500 mg/kg) or gabapentin (used as positive control drug, $70 \mathrm{mg} / \mathrm{kg}$ ) and hyperalgesia was tested 1, 2, 4, 6,8 and $24 \mathrm{~h}$ time points post treatment on the right hind paw. After the $24 \mathrm{~h}$ measurement, animals were treated twice a day (10 a.m and 6 p.m) and neuropathic pain-like behavior was evaluated the next day before and $2 \mathrm{~h}$ after the first administration of the day (10 a.m).

\section{$\mathrm{PGE}_{2}$-induced mechanical hyperalgesia}

After assessment of the basal reaction of male mice to von Frey hair, animals were orally treated with vehicle (DMSO/Tween), MECM (500 mg/kg) or dipyrone (used as positive control drug, $120 \mathrm{mg} / \mathrm{kg}$ ) and 1 hour later, they received $\mathrm{PGE}_{2}(0.1 \mathrm{nmol} / \mathrm{paw})$ under the subplantar aponevreous. Frequency response to von Frey hair stimulation was measured 1, 2, 4, 6 and $8 \mathrm{~h}$ time points post $\mathrm{PGE}_{2}[13]$.

In another set of experiment, treatments were given orally 1 hour after $\mathrm{PGE}_{2}$ (therapeutic) and pain was evaluated till $8 \mathrm{~h}$ post $\mathrm{PGE}_{2}$ injection. The post treatments with MECM (500 mg/kg) or dipyrone $120 \mathrm{mg} / \mathrm{kg}$, were evaluated in absence and in presence of glibenclamide ( $5 \mathrm{mg} / \mathrm{kg}$, i.p), an inhibitor of ATP - sensitive potassium channels. The inhibitor was used to evaluate the participation of ATP-dependant potassium channel in the analgesic effects of MECM. Antagonist was administered 30 min before MECM or dipyrone.

\section{CFA - induced thermal hyperalgesia}

Male mice latency time of reaction against infrared radiation (intensity $15 \%$ in the paw), was measured and animals were then treated orally with vehicle $(10 \mathrm{~mL} / \mathrm{kg})$, MECM (500 mg/kg p.o.) or dipyrone (120 mg/kg, p.o.). One hour after the treatment, they were intraplantarly injected with $20 \mu \mathrm{l}$ of CFA and pain behavior was again assessed 1, 2, 4, 6, 8 and $24 \mathrm{~h}$ time points after CFA injection, as previously described [14].

\section{Capsaicin-induced spontaneous nociception}

Male mice were treated with vehicle, MECM $(500 \mathrm{mg} / \mathrm{kg}$, p.o) or with capsazepine $(11.3 \mu \mathrm{g} / \mathrm{paw})$ and acclimated in glace funning for at least $20 \mathrm{~min}$ before challenged with $1.6 \mu \mathrm{g} /$ paw of capsaicin. Pain behavior was evaluated at 1 , 2, 4 or $6 \mathrm{~h}$ time points after MECM treatment. Different groups of animals were used at each time point. After capsaicin injection, animals were returned in individual funning and observed for the consecutive $5 \mathrm{~min}$. The time the animal spent licking the injected paw was timed with chronometer and consider as indicative of pain [15]. Capsazepine used as positive control was injected in situ and appropriate control was conducted.

To assess whether the effect of MECM was mediated through cannabinoid $\mathrm{CB}_{1}$ receptors that are collocated in the same neurons with TRPV1 capsaicin sensitive receptor [16], the effect of the extract was assessed in animals previously treated with rimonabant $(10 \mathrm{mg} / \mathrm{kg}, \mathrm{p} . \mathrm{o})$, an inverse agonist of $\mathrm{CB}_{1}$ receptor. WIN 55,212-2 ((R)-(+)-[2,3-Dihydro-5-methyl-3[(4-morpholinyl)methyl] pyrrolo[1,2,3-de]1,4-benzoxazinyl]-(1-naphthalenyl) methanone, $3 \mathrm{mg} / \mathrm{kg}$, i.p) was used as positive control. Appropriate controls were conducted both for rimonabant and WIN 55,212-2. In the course of experiment, rimonabant was given $30 \mathrm{~min}$ before WIN 55,212-2 and MECM and animals were challenged with capsaicin $30 \mathrm{~min}$ after WIN 55,212-2 or $1 \mathrm{~h}$ after MECM administrations. This time schedule was chosen base on the time course effect of the extract in previous experiments as well as that of the WIN 55,212-2 and rimonabant in the literature [17].

\section{Drugs}

Complete Freund Adjuvant (CFA), capsaicin, capsazepine, Win 55,212-2, prostaglandine $\mathrm{E}_{2}$, dipyrone, gabapentin and cremophore were purchased from Sigma Chemical CO, (St. Louis, MO, USA). Glibenclamide was obtained from RBI and rimonabant from Sanofi. Gabapentin and dipyrone were prepared in saline. Plant extract and Win 55,212-2 were prepared in saline containing $5 \%$ of DMSO and $5 \%$ Tween 80 which was further used as vehicle in control animals. Glibenclamide was prepared in saline containing $2 \%$ of DMSO and $2 \%$ Tween 80 . Capsaicin stock solution $\left(10^{-2} \mathrm{M}\right)$ was prepared by successively dissolving capsaicin in $10 \%$ ethanol, $10 \%$ Tween 80 and $80 \% \mathrm{NaCl} 0.9 \%$. The stock solution was further diluted in saline upon administration to $80 \mu \mathrm{g} / \mathrm{ml}$. Stock solution of capazepine $\left(10^{-2} \mathrm{M}\right)$ was prepared in $20 \%$ ethanol and further diluted upon administration to the concentration of $565 \mu \mathrm{g} / \mathrm{ml}$ using saline. Prostaglandine $E_{2}$ stock solution $\left(10^{-3} \mathrm{M}\right)$ was prepared in $10 \%$ ethanol and further diluted 200 folds to a final solution of $1.76 \mu \mathrm{g} / \mathrm{ml}$ using Saline. Rimonabant was suspended in $5 \%$ DMSO and $0.5 \%$ cremophore. In all cases, vehicle solutions were prepared just before experiments and and used in control groups.

\section{Statistical analysis}

Data are expressed as mean \pm standard error of the mean of 5-7 individual animals. Data were analyzed by either one way ANOVA followed by Tukey post hoc test or two way ANOVA followed by Bonferonni as post hoc test using the GraphPad Prism software (GraphPad Software Inc., San Diego, CA). $P<0.05$ was considered significant. 


\section{Results}

Effects of MECM on CFA - induced mechanical hyperalgesia

CFA injection into the mice paw induced mechanical hyperalgesia when assessed by von Frey stimulation as evidenced by the significant $(p<0.001)$ increase in the baseline frequency response. This hypersensitivity was significantly reduced by previous treatment of animals with gabapentin and also with MECM. It is worth noting that following 2 day administration of MECM at the dose of $500 \mathrm{mg} / \mathrm{kg}$, the antihyperalgesic effect of MECM was maintained for up to 5 days. The reinitiating of treatment after the animals have recovered their hypersensitivity induced a progressive and long lasting analgesic effect, the higher dose being the most effective (Fig. 1).

Effects of MECM on mechanical hyperalgesia in mice with partial sciatic nerve ligation

Five days after surgery, a significant increase $(p<0.001)$ on the baseline frequency response was observed in all animals. In the acute treatment (Fig. 2a), oral administration of MECM (500 mg/kg, p.o.) significantly reduced the mechanical hyperalgesia caused by partial sciatic nerve ligation. The effect of the extract as that of gabapentin, started $1 \mathrm{~h}$ after administration. The antinociceptive effects of the two substances were maintained for up to $8 \mathrm{~h}$; but $24 \mathrm{~h}$ after the administration, the sensitivity of treated animals was equal to that of control group. When given twice a day and evaluated in the next days (Fig. 2a), gabapentin did not show any long lasting effect up to the end of the experiment while MECM progressively and significantly inhibited the mechanical hyperalgesia (Fig. 2a). In contrast, when the treatment was given twice a day and pain behavior assessed $2 \mathrm{~h}$ after the first treatment of the day, either extract or gabapentin, almost completely inhibited the hyperalgesia (Fig. 2b).

\section{Effects of MECM on $\mathrm{PGE}_{2}$ - induced mechanical hyperalgesia}

Intraplantar injection of $\mathrm{PGE}_{2}$ resulted in a significant $(p<0.01)$ hyperalgesia to mechanical stimulation when assessed by von Frey hair. $\mathrm{PGE}_{2}$-induced hyperalgesia was significantly reduced by dipyrone $(120 \mathrm{mg} / \mathrm{kg}$, p.o. $)$ and by MECM (500 mg/kg, p.o.) when both were given as preventive treatment (Fig. 3a). As shown in Fig. 3b, both substances significantly inhibited $\mathrm{PGE}_{2}$-induced hyperalgesia when administered as a therapeutic scheme of treatment. However, glibenclamide significantly reduced the antihyperalgesic effect of dipyrone but failed to prevent that of MECM although an effect was observed at the 4th hour (Fig. 3c).

\section{Effects of MECM on CFA - induced thermal hyperalgesia}

CFA injected in ventral aponevreous of mice's paw induced a significant $(p<0.01)$ thermal hyperalgesia. The reaction latency time of animals was reduced by $60 \% 1$ hour after CFA injection. Both dipyrone (120 mg/kg, p.o.) and MECM (500 mg/kg, p.o.) given one hour before CFA, significantly increased the latency time (Fig. 4a). The two drugs significantly reduced the sensitivity to thermal stimulation by

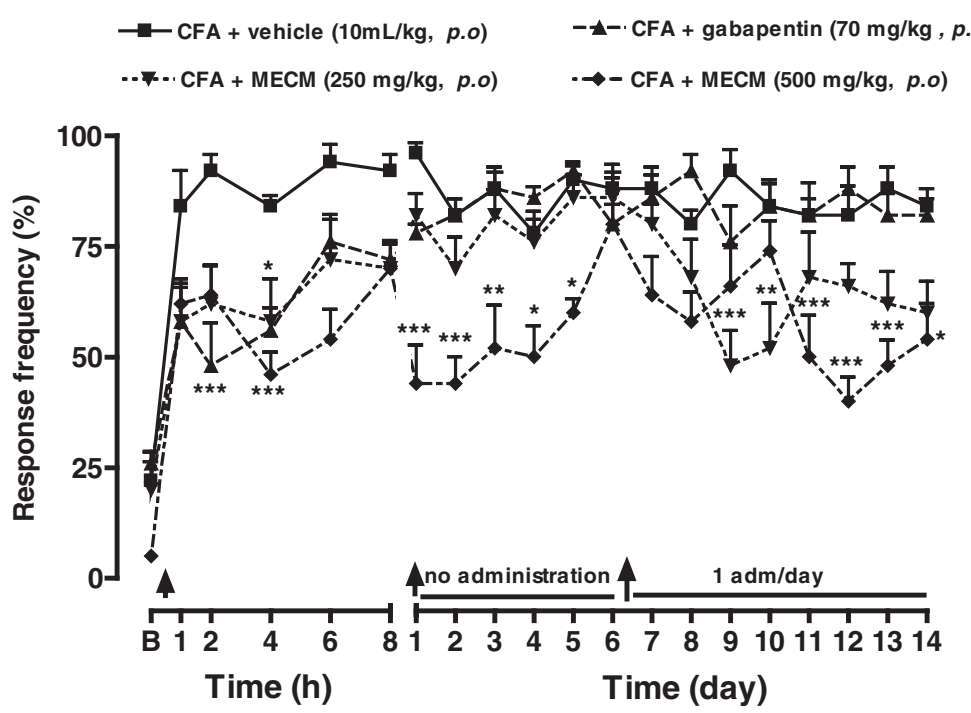

Fig. 1 Effects of oral administration of the methanol/methylene chloride extract of the stem bark of Croton macrostachyus (MECM) on the mechanical hyperalgesia induced by von Frey hair $(0.4 \mathrm{~g})$ in CFA (20 $\mu \mathrm{l} /$ paw) inflamed mice paw. In persistent treatment, response to pain was evaluated before the treatment of the day, when given. $B=$ basal response to mechanical stimulation. $N=5 ;{ }^{a} p<0.05 ;{ }^{b} p<0.01 ;{ }^{c} p<0.001$ significantly different compared to vehicle (ANOVA two way and Bonferoni as post hoc test) 

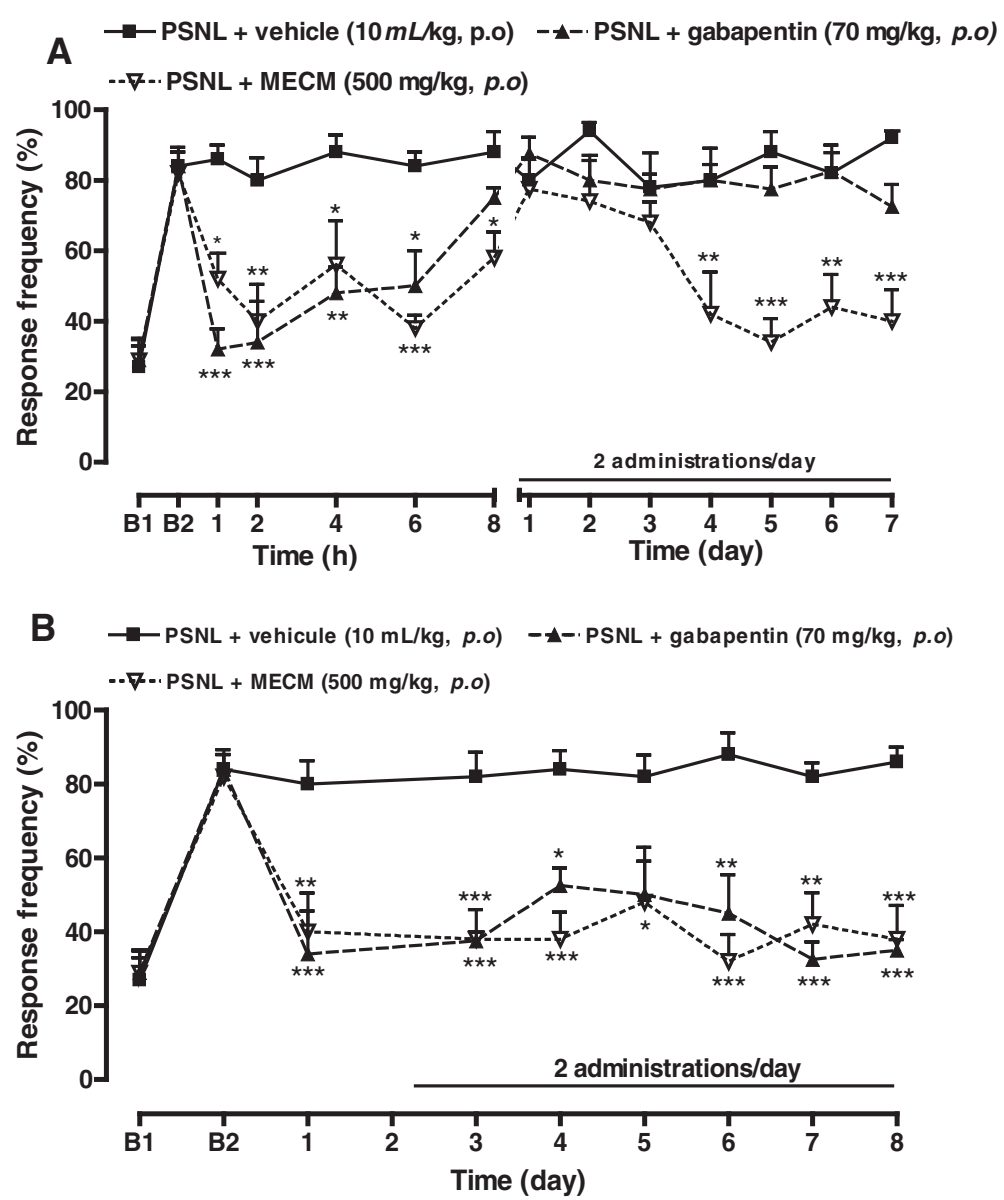

Fig. 2 Effect of oral administration of the methanol/methylene chloride extract of the stem bark of Croton macrostachyus (MECM) on the mechanical hyperalgesia assessed with von Frey hair $(0.4 \mathrm{~g})$ in mice paw after sciatic nerve partial ligation (PSNL). In panel (a), response to pain was evaluated before the first administration of the day while in panel (b) it was evaluated $2 \mathrm{~h}$ after the first administration of the day. $N=5$; ${ }^{a} p<0.05 ;{ }^{b} p<0.01 ;{ }^{c} p<0.001$ significantly different compared to vehicle at each time point. $\mathrm{B} 1=$ basal response to mechanical stimulation before operation, $\mathrm{B} 2$ = basal response to mechanical stimulation 5 days after operation

24.5 and $37.3 \%$, respectively as calculated from area under the curve (Fig. 4b).

\section{Effects of MECM on capsaicin-induced pain}

Oral administration of MECM induced a significant inhibition of pain induced by intraplantar injection of capsaicin. The extract was effective when dosed one hour after administration and its effect lasted for up to $4 \mathrm{~h}$ (Fig. 5a).

It is well known that capsaicin activates TRPV1 cation channels. These channels are found in the same $C$ nerve fibers with the cannabinoid $C_{1}$ receptors [16]. Thus, we hypothesized that activation of these $\mathrm{CB}_{1}$ receptors could inhibit the capsaicin induced pain. So, the effect of WIN 55,212-2 (a $\mathrm{CB}_{1}$ agonist) was tested and showed antinociceptive effect on this model. To evaluate whether the effect of MECM was mediated through $\mathrm{CB}_{1}$ receptors, its activity as well as that of WIN 55,212-2 was evaluated in animals pretreated with rimonabant (an antagonist of cannabinoid $\mathrm{CB}_{1}$ receptors). Rimonabant completely reversed the antinociceptive effect of WIN 55,212-2 as expected, but failed to inhibit the effect of MECM (Fig. 5b).

\section{Discussion}

The present study investigates the antinociceptive effects of the methanol/methylene chloride extract of Croton macrostachyus (MECM) in models of persistent inflammatory and neuropathic pain and explored its preliminary mechanism of action. Results demonstrated that MECM possesses orally antinociceptive property when assessed in both CFA and sciatic nerve partial ligation as well as in prostaglandin $\mathrm{E}_{2}\left(\mathrm{PGE}_{2}\right)$-induced acute pain. MECM also showed significant inhibitory effect in capsaicin induced pain, an effect that was not prevented by rimonabant, a CB1 receptor reverse agonist or by glibenclamide, a ATP- dependent potassium channel inhibitor. It is important to mention, that the antinocicepetive property of MECM as demonstrated in the present paper corroborates many previous works carried out in 


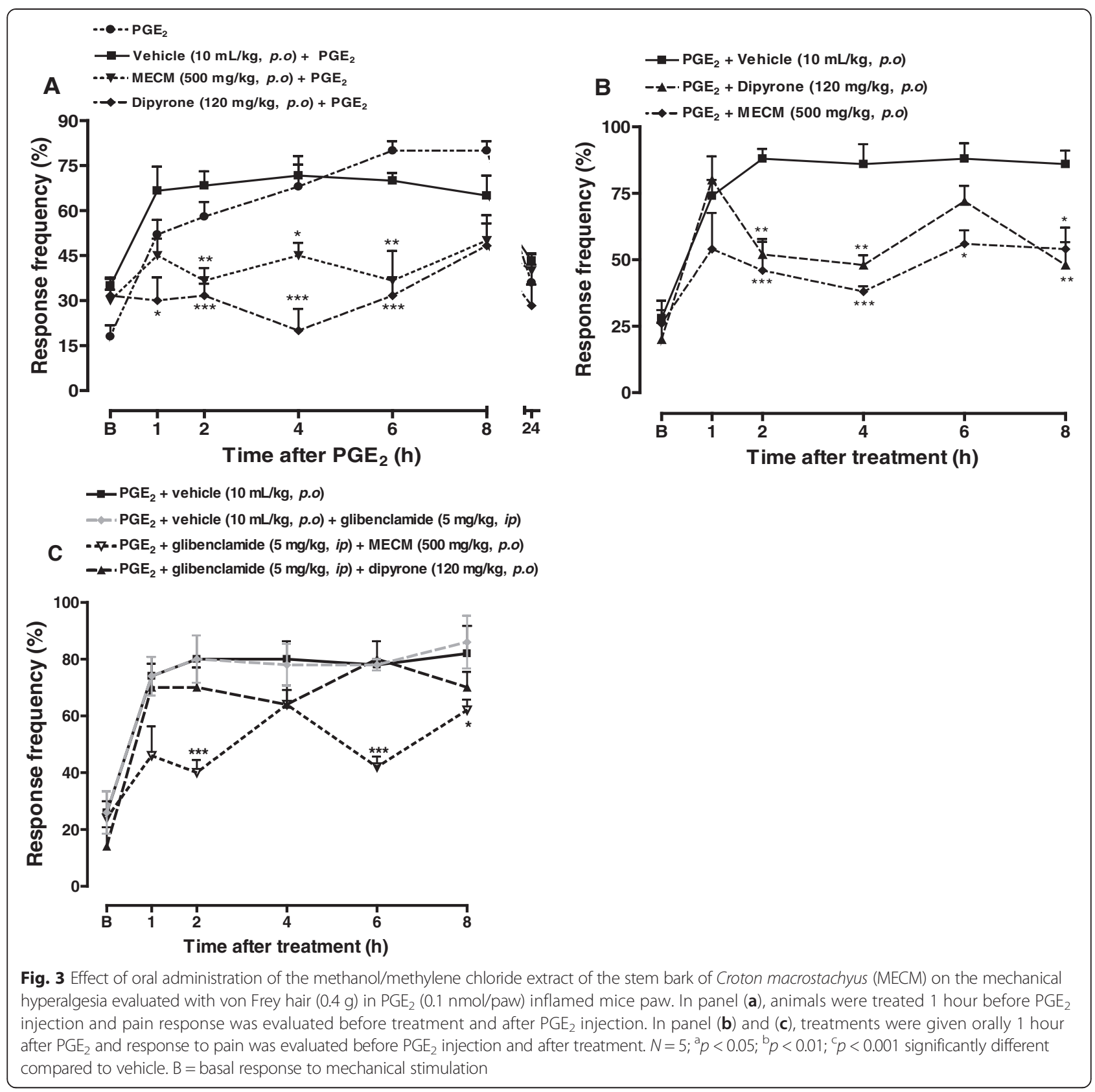

other plants belonging to the genus Croton [18-20]. However, new experiments should be conducted to isolate and chemically characterize the active compound(s) present in the MECM.

Hyperalgesia resulting from CFA injection in animals' paw is a well known and characterized model of pain involving both the peripheral and the central nervous system. Indeed, CFA injection induces the release of histamine and serotonin from mast cells through the degranulation process and activates inflammatory cells to release cytokines (TNF- $\alpha$, IL-1 $\beta$, IL-6) and chemokines (MCP$1, \mathrm{KC}, \mathrm{IP}-10)$ both at the periphery and at the central nervous system [21, 22] Cytokines are responsible for the hypersensitisation of peripheral and central neurons, a phenomenon that includes the appearance of inducible proteins, up-regulation and activation of various membrane and intracellular pathways. It is now well recognized that CFA up regulates and potentiates voltage-gated sodium channels, GluR1 and TRPV1 receptors [23-25] which participate in the maintenance of persistent mechanical and thermal inflammatory pain. Herein, our data demonstrated that MECM significantly reduced the mechanical hyperalgesia induced by intraplantar injection of CFA. Moreover, the antinociceptive effect of MECM was maintained for up to 5 days after two administrations in the first $24 \mathrm{~h}$. These results suggest that MECM might 


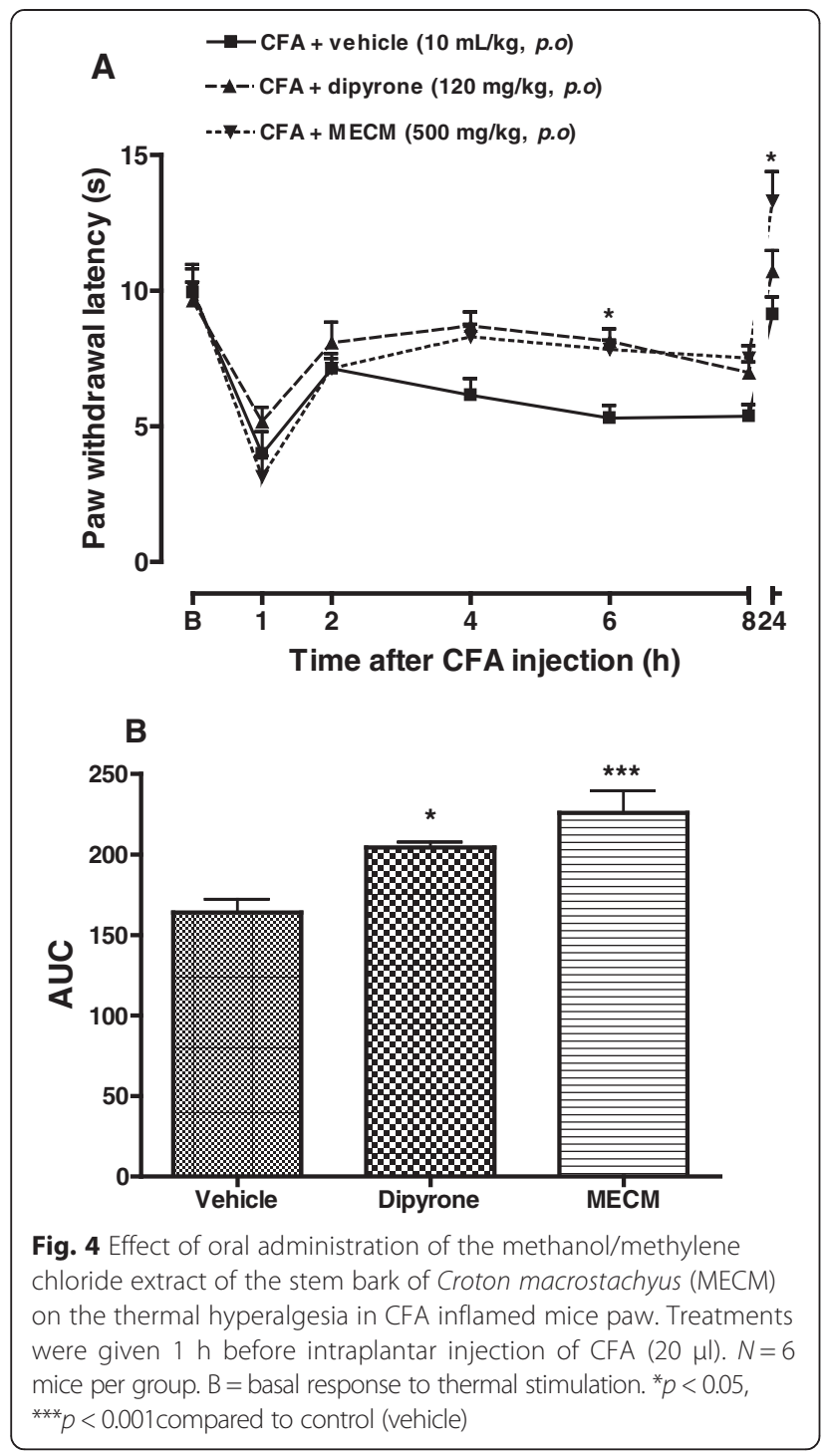

interfere with the acute pain sensitization as well as the over expression of pain regulatory cytokines and proteins. In other to verify this hypothesis, animal were left untreated until the sensitivity returns to the control point, then the treatment was reinitiated. It was observed that the MECM administered once a day, produced antihyperalgesic effect that reappears after the third day, showing a progressive effect. It can then be thought that MECM do not inhibit the installation of pain but rather interact with signaling pathways that induce mechanical pain in inflammatory conditions. Another possibility is that MECM may be able to reduce the well-established chronic pain. This hypothesis was evaluated by testing MECM on a well installed neuropathic pain induced by PSNL. MECM significantly reduced the PSNL neuropathic pain. On this model of pain generally known as resistant to treatment, MECM almost completely inhibited the hyperalgesia 2 hours after its oral administration. Relevantly, a long lasting effect of
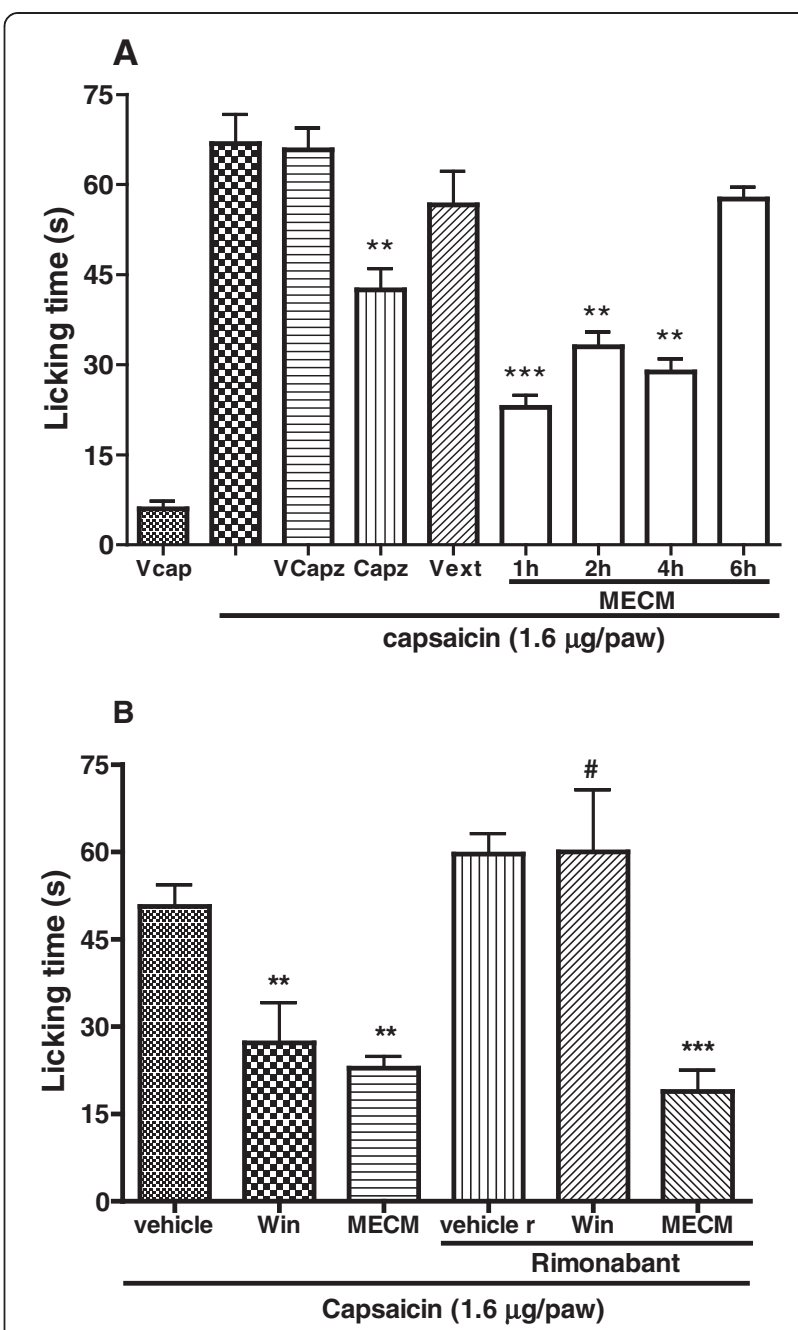

Fig. 5 Effect of oral administration of the methanol/methylene chloride extract of the stem bark of Croton macrostachyus (MECM, 500 mg/kg, po) on the spontaneous pain induced by capsaicin. Panel (a) shows the time course effect of MECM in different groups of animals. Panel (b) presents the effect of rimonabant (SR 141716, $10 \mathrm{mg} / \mathrm{kg}$, po) on the analgesic activity of MECM and WIN 55212-2 (Win, 3 mg/kg, ip) on nociception induced by capsaicin. MECM was given $1 \mathrm{~h}$ before intraplantar injection of capsaicin while rimonabant (10 mg/kg, p.o) was given per os $30 \mathrm{~min}$ before Win and MECM. V = vehicle, cap = capsaicin, capz = capsazepine, ext $=$ extract. $N=4$ (Vcap) to 7 mice per group. ${ }^{* *} p<0.01,{ }^{* * *} p<0.001$ significantly different compared to respective controls. \# $p<0.01$ significantly different compared to the same treatment without rimonabant

MECM was observed in this model from the fourth day after the initiation of the treatment. This effect was observed during the 14 days of treatment. These results suggest that MECM may have cumulative effects or may interfere with slow regulatory processes such as proteins and mediators expression. Further experiments are necessary to prove this hypothesis.

Pro-inflammatory substances and proteins released or up regulated by CFA and implicated in the mechanical 
hyperalgesia including inducible nitric oxide synthase and cyclooxygenase-2 [26]. Subsequent upregulation of $\mathrm{PGE}_{2}$ production but also of $\mathrm{PGE}_{2}$ receptors have been demonstrated both in inflammatory pain and in partial sciatic nerve ligation [27]. In order to determine whether MECM interferes with the $\mathrm{PGE}_{2}$ pathway, it was tested as preventive and therapeutic scheme of treatment on the mechanical hyperalgesia induced by this inflammatory mediator. In both cases, MECM exhibited a significant antihyperalgesic effect. As MECM was able to reduce pain when given after $\mathrm{PGE}_{2}$ injection, it can be conclude that this extract inhibits the downstream $\mathrm{PGE}_{2}$ pathway or interact with ion channels that are involve in nerve action potential or nerve conductivity.

Opening of the ATP-sensitive potassium channels (K-АтP) have been shown as the end mechanism of the peripheral effect of many analgesics such as morphine [28], dypirone [29], diclofenac [30], xylazine [31], sildenafil [32] and even plant derivatives [11]. In order to determine whether or not this pathway is involved in the activity of MECM, its antinociceptive effect was evaluated in animals previously treated with glibenclamide, an inhibitor of K-АTP channels. Glibenclamide failed to significantly antagonize the analgesic effect of MECM, implying that its antinociceptive action is likely unrelated with the activation of the K-

The linkage of $\mathrm{PGE}_{2}$ to its cellular receptors leads to the activation of protein kinase $\mathrm{C}$ (PKC) and protein kinase A (PKA) resulting in the release of sympathetic amines and the sympathetic pain [33] or in the activation and phosphorylation of numbers of ion channels [34], respectively. One of the channels target by PKA and PKC activation is TRPV1 [35]. This channel is one of the main receptors involve in the sensitization and the maintenance of mechanical hyperalgesia in both inflammatory and neuropathic pain [36]. It can be activated by noxious heat, low $\mathrm{pH}$ or chemicals [37]. For this reason, MECM was tested on thermal hyperalgesia induced in CFA-inflamed mice, and relevantly, the extract significantly reduced the hyperalgesia, indicating a possible inhibition of TRPV1 receptor.

To further ascertain the mechanism of action of MECM, it was assesseed on pain induced by capsaicin, a natural product that specifically and directly activates TRPV1 receptor [38]. Here, MECM showed a significant antinociception effect on capsaicin-induced pain that was maintained for up to $4 \mathrm{~h}$, strengthening the hypothesis that the antihyperalgesic effect of this extract is at least partially mediated by the inhibition of TRPV1 channel.

There is evidence that TRPV1 and CB1 receptors are colocalized in the same neurons both at the periphery and central nervous system and that the activation of CB1 receptors may inhibit TRPV1 receptors $[16,38]$. To verify whether the inhibition of capsaicin-induced pain observed with MECM is mediate by the activation of CB1 receptor, it was tested in animals that have been previously treated with rimonabant, an antagonist of CB1 receptor. Rimonabant completely reversed the antinociceptive effect of WIN 55,212-2 (cannabinoid agonist), but failed to affect that of MECM, suggesting that the effect of this extract is not mediated through $\mathrm{CB} 1$ receptor.

\section{Conclusions}

Taking all together, the present study demonstrates that methanol/methylene chloride extract of the stem bark of Croton macrostachyus possesses relevant oral antinociceptive effects both when assessed in acute, chronic, inflammatory and neuropathic pain. The long lasting MECM antinociceptive effect seems to be mediated, at least partially, through the modulation of TRPV1 receptors.

\section{Competing interest}

The authors declare that they have no competing interest.

\section{Authors' contributions}

TBN and JBC designed the work. TBN, RCD, AFP and ELA conducted the work, collected and analysed the data. TBN, RCD and JBC drafted the manuscript and revised it critically. All authors agree to be accountable for all aspects of the work.

\section{Acknowledgement}

The authors wish to express their gratitude to TWAS (Academy of Science of Developing Countries) and CNPq (Conselho Nacional de Desenvolvimento Cientifico e Tecnologico, Brazil) for the fellowship awarded to TBN.

\section{Author details}

${ }^{1}$ Laboratory of Animal Physiology and Phytopharmacology, Department of Animal Biology, Faculty of Sciences, University of Dschang, P.O. Box 67, Dschang, Cameroon. ${ }^{2}$ Department of Pharmacology, Centre of Biological Sciences, Universidade Federal de Santa Catarina UFSC, Campus Universitario, Rua Ferreira Lima 82, Trindade, 88049-900 Florianopolis, SC, Brazil.

${ }^{3}$ Laboratory of Autoimmunity and Immunopharmacology, Campus Araranguá, Universidade Federal de Santa Catarina, 88900-000 Araranguá, SC, Brazil. ${ }^{4}$ Centre of inovation and preclinic studies (CIEnP), Av. Luiz Boiteux Piazza 1302, Cachoeira do Bom Jesus, Florianópolis, SC, Brazil.

Received: 19 December 2014 Accepted: 10 August 2015 Published online: 25 August 2015

\section{References}

1. Wen YR, Tan PH, Cheng JK, Liu YC, Ji RR. Microglia: a promising target for treating neuropathic and postoperative pain, and morphine tolerance. J Formos Med Assoc. 2011;110:487-94.

2. Li Y, Zhang Y, Liu D, H-y L, W-g H, Dong Y-s. Curcumin attenuates diabetic neuropathic pain by downregulating TNF-a in a rat model. Int J Med Sci. 2013;10:377-81.

3. Luo H, Xu IS, Chen Y, Yang F, Yu L, Li G-X, et al. Behavioral and electrophysiological evidence for the differential functions of TRPV1 at early and late stages of chronic Inflammatory Nociception in Rats. Neurochem Res. 2008;33:2151-8.

4. Gilron I, Bailey JM, Tu D, Holden RR, Weaver DF, Houlden RL. Morphine, gabapentin, or their combination for neuropathic pain. N Engl J Med. 2005;352:1324-34.

5. Calixto JB, Beirith A, Ferreira J, Santos AR, Filho VC, Yunes RA. Naturally occurring antinociceptive substances from plants. Phytother Res. 2000;14:401-18.

6. Gurib-Fakim A. Medicinal plants: traditions of yesterday and drugs of tomorrow. Mol Aspects Med. 2006;27:1-93.

7. Albrecht JED. Livre de main de graine d'arbre du Kenya. Centre Muguga: Kenya de graine de sylviculture de GTZ; 1993. 
8. Bein E. Arbres et arbustes utiles en Erythrée. Nairobi: Unité régionale de conservation de sol (RSCU); 1996.

9. Kamanyi A, Mbiantcha M, Nguelefack TB, Ateufack G, Watcho P, Ndontsa BL, et al. Anti-Nociceptive and anti-inflammatory activities of extracts from the stem bark of Croton macrostachyus (Euphorbiaceae) in mice and rats. J Compl Alter Med. 2009;6:Art 20.

10. Tene M, Ndontsa BL, Tane P, Tamokou J, Kuiate J-R. Antimicrobial diterpenoids and triterpenoids from the stem bark of Croton macrostachyus. Int J Biol Chem Sci. 2009;3:538-44.

11. Nquelefack TB, Dutra RC, Paszcuk AF, Andrade EL, Tapondjou LA, Calixto JB. Antinociceptive activities of the methanol extract of the bulbs of Dioscorea bulbifera L. var sativa in mice is dependent of NO-cGMP-ATP-sensitive- $\mathrm{K}^{+}$ channel activation. J Ethnopharmacol. 2010;128:567-74.

12. Quintao NL, Medeiros R, Santos AR, Campos MM, Calixto JB. The effects of diacerhein on mechanical allodynia in inflammatory and neuropathic models of nociception in mice. Anesth Analg. 2005;101:1763-9.

13. Da Silva KA, Manjavachi MN, Paszcuk AF, Pivatto M, Viegas Jr C, Bolzani VS, et al. Plant derived alkaloid (-)-cassine induces anti-inflammatory and anti-hyperalgesics effects in both acute and chronic inflammatory and neuropathic pain models. Neuropharmacol. 2012;62:967-77.

14. Sotocinal SG, Sorge RE, Zaloum A, Tuttle AH, Martin LJ, Wieskopf JS, et al The Rat Grimace Scale: a partially automated method for quantifying pain in the laboratory rat via facial expressions. Mol Pain. 2011:7:55.

15. Meotti FC, Luiz AP, Pizzolatti MG, Kassuya CA, Calixto JB, Santos AR. Analysis of the antinociceptive effect of the flavonoid myricitrin: evidence for a role of the L-arginine-nitric oxide and protein kinase C pathways. J Pharmacol Exp Ther. 2006;316:789-96.

16. Binzen U, Greffrath W, Hennessy S, Bausen M, Saaler-Reinhardt S, Treede R-D. Co-expression of the voltage-gated potassium channel Kv1.4 with transient receptor potential channels (TRPV1 and TRPV2) and the cannabinoid receptor CB1 in rat dorsal root ganglion neurons. Neuroscience. 2006;142:527-39.

17. Hagues G, Costentin J, Duterte-Boucher D. Modulation of morphine and alcohol motor stimulant effects by cannabinoid receptors ligands. Behav Brain Res. 2007;178:274-82.

18. Suárez Al, Compagnone RS, Salazar-Bookaman MM, Tillett S, Monache FD, Di Giulio C, et al. Antinociceptive and anti-inflammatory effects of Croton malambo bark aqueous extract. J Ethnopharmacol. 2003;88:11-4.

19. Santos FA, Jeferson FA, Santos CC, Silveira ER, Rao VSN. Antinociceptive effect of leaf essential oil from Croton sonderianus in mice. Life Sci. 2005;77:2953-63.

20. Zhao J, Fang F, Yu L, Wang G, Yang L. Anti-nociceptive and anti-inflammatory effects of Croton crassifolius ethanol extract. J Ethnopharmacol. 2012:42:367-73.

21. Raghavendra $V$, DeLeo JA. The role of astrocytes and microglia in persistent pain. In: Hertz L, editor. Non-neuronal cells in the nervous system: function and dysfunction. Amsterdam: Elsevier; 2003. p. 951-66.

22. Hui J, Zhang Z-J, Zhang X, Shen Y, Gao Y-J. Repetitive hyperbaric oxygen treatment attenuates Complete Freund's Adjuvant-induced pain and reduces glia-mediated neuroinflammation in the spinal cord. J Pain. 2013;14:747-58.

23. Peng HY, Chen GD, Hsieh MC, Lai CY, Huang YP, Lin TB. Spinal SGK1/GRASP$1 /$ Rab4 is involved in complete Freund's adjuvant-induced inflammatory pain via regulating dorsal horn GluR1-containing AMPA receptor trafficking in rats. Pain. 2012;153:2380-92.

24. Huang CP, Chen HN, Su HL, Hsieh CL, Chen WH, Lai ZR, et al. Electroacupuncture reduces carrageenan- and CFA-induced inflammatory pain accompanied by changing the expression of Nav1.7 and Nav1.8, rather than Nav1.9, in mice dorsal root ganglia. Evid Based Complement Alternat Med. 2013. doi:10.1155/2013/312184.

25. Liang $L$, Fan $L$, Tao B, Yaster M, Tao YX. Protein Kinase B/Akt is required for Complete Freund's Adjuvant-induced upregulation of Nav1.7 and Nav1.8 in primary sensory neurons. J Pain. 2013;14:638-47.

26. Cunha TM, Waldiceu A, Jr V, Fukada SY, Guerrero ATG, Santodomingo-Garzón $T$, et al. TNF- $a$ and IL-1 $\beta$ mediate inflammatory hypernociception in mice triggered by B1 but not B2 kinin receptor. Eur J Pharmacol. 2007;573:221-9.

27. Ma W, Eisenach JC. Four $\mathrm{PGE}_{2}$ EP receptors are up-regulated in injured nerve following partial sciatic nerve ligation. Exp Neurol. 2003;183:581-92.

28. Ocaña M, Del Pozo E, Barrios M, Robles LI, Baeyens JM. An ATP-dependent potassium channel blocker antagonizes morphine analgesia. Eur J Pharmacol. 1990;186:377-8.

29. Alves D, Duarte I. Involvement of ATP-sensitive $\mathrm{K}^{+}$channels in the peripheral antinociceptive effect induced by dipyrone. Eur J Pharmacol. 2002:444:47-52
30. Alves DP, Tatsuo MA, Leite R, Duarte ID. Diclofenac-induced peripheral antinociception is associated with ATP-sensitive $\mathrm{K}^{+}$channels activation. Life Sci. 2004;74:2577-91

31. Vale ML, Rolim DE, Cavalcante IF, Ribeiro RA, Souza MH. Role of NO/cGMP/KATP pathway in antinociceptive effect of sildenafil in zymosan writhing response in mice. Inflamm Res. 2007:56:83-8.

32. Romero TR, Duarte ID. Involvement of ATP-sensitive $\mathrm{K}^{+}$channels in the peripheral antinociceptive effect induced by the alpha(2)-adrenoceptor agonist xylazine. J Pharmacol Sci. 2009;111:323-37.

33. Loram LC, Fuller A, Fick LG, Cartmell T, Poole S, Mitchell D. Cytokine profiles during carrageenan-induced inflammatory hyperalgesia in rat muscle and hind paw. J Pain. 2007;8:127-36.

34. Claudino RF, Kassuya CA, Ferreira J, Calixto JB. Pharmacological and molecular characterization of the mechanisms involved in prostaglandin $E_{2}$-induced mouse paw edema. J Pharmacol Exp Ther. 2006;318:611-8.

35. Wang W, Cao X, Liu C, Liu L. Cannabinoid WIN 55,212-2 inhibits TRPV1 in trigeminal ganglion neurons via PKA and PKC pathways. Neurol Sci. 2012;33:79-85

36. Schnizler K, Shutov LP, Van Kanegan MJ, Merrill MA, Nichols B, McKnight GS, et al. Protein kinase A anchoring via AKAP150 is essential for TRPV1 modulation by forskolin and prostaglandin E2 in mouse sensory neurons. J Neurosci. 2008:28:4904-17.

37. Cao E, Cordero-Morales JF, Liu B, Qin F, Julius D. TRPV1 channels are intrinsically heat sensitive and negatively regulated by phosphoinositide lipids. Neuron. 2013;77:667-79.

38. Yang $Y$, Yang H, Wang Z, Varadaraj K, Kumari SS, Mergler S, et al. Cannabinoid receptor 1 suppresses transient receptor potential vanilloid 1-induced inflammatory responses to corneal injury. Cell Signal. 2013:25:501-11.

\section{Submit your next manuscript to BioMed Central and take full advantage of:}

- Convenient online submission

- Thorough peer review

- No space constraints or color figure charges

- Immediate publication on acceptance

- Inclusion in PubMed, CAS, Scopus and Google Scholar

- Research which is freely available for redistribution 